\title{
Severity of rust infection in soybean genotypes with partial resistance as a function of temperature and leaf wetness duration
}

\author{
B.C.M. Juliatti ${ }^{1}$, E.A. Pozza ${ }^{1}$ and F.C. Juliatti ${ }^{2}$ \\ ${ }^{1}$ Universidade Federal de Lavras, Programa de Pós-Graduação em Fitopatologia, \\ Lavras, MG, Brasil \\ ${ }^{2}$ Universidade Federal de Uberlândia, Instituto de Ciências Agrárias, Uberlândia, \\ MG, Brasil \\ Corresponding author: F.C. Juliatti \\ E-mail: juliatti@ufu.br \\ Genet. Mol. Res. 20 (2): gmr18781 \\ Received December 06, 2020 \\ Accepted April 22, 2021 \\ Published May 31, 2021 \\ DOI http://dx.doi.org/10.4238/gmr18781
}

\begin{abstract}
Soybean cultivars with resistance against Asian soybean rust (ASR) are necessary to maintain plant yield when control methods become ineffective. We examined the influence of temperature $(18,21$, 24,27 and $\left.30^{\circ} \mathrm{C}\right)$ and leaf wetness duration $(0,6,12,24$ and 48 hours) on the penetration and temporal progress of ASR in soybean genotypes with different levels of partial resistance from the Federal University of Uberlandia breeding program. The genotypes were selected in the field from 100 progenies during 15 years under ASR epidemic conditions. Information on inheritance and molecular markers for disease resistance was available for our study. There were significant differences $(\mathrm{P}=0.001)$ in the area under the disease progress curve (AUDPC) between genotypes under the interaction of the binomial (temperature $x$ leaf wetness duration - LWD) and for incubation period at different temperatures. No signs or symptoms of rust appeared at temperatures below $18^{\circ} \mathrm{C}$ or above $30^{\circ} \mathrm{C}$. The relationship between temperature and LWD affect the AUDPC and temperature affects incubation period. The highest AUDPC values occurred at $24^{\circ} \mathrm{C}$ and leaf wetting period of 24 hours, and the lowest values were achieved at temperatures above $27^{\circ} \mathrm{C}$. (Cultivar Desafio RR 8473 RSF) showed susceptibility to ASR.ASR lesions started to appear on average at least 15 days after infection in partially resistant genotypesF8 BRSGO Luziânia X Potenza, F8 BRSGO Caiapônia X Potenza, and F8 BRSGO Caiapônia X IAC100, which also
\end{abstract}


had lower AUDPC and severity values, during the monocycle experiment. We conclude that ASR is shifting to a longer incubation period and fast sporulation induction after uredinia formation. These genotypes can be used in the field, with less need for fungicides helping avoid the emergence of new ASR pathotypes and races with low sensitivity to currently used fungicides.

Key words: Glycine max; Incubation period; Rust; Latency

\section{INTRODUCTION}

The fungal disease, Asian soybean rust (ASR), caused by the fungus Phakopsora pachyrhizi (Phakopsoraceae), is considered the most severe and destructive disease of soybean (Glycine max) plants in Brazilian agriculture. The symptoms of ASR can appear at any time in the phenological cycle of the crop, but generally at the flowering stage (Yorinori, 2005). The success of infection depends on a sequence of events that comprises spore germination, appressorium formation and penetration. Each of these events and subsequent colonization and sporulation are influenced by interactions between biotic and abiotic factors (Vale etal., 1990). The abiotic factors, such as, foliar dew period and temperature, heavily influence the temporal progression of the pathogen (Juliatti et al., 2005). Hours of dew period can contribute to the initial fungal infection. Regions with weeks of longer dew periods, higher humidity, and deposition of the water film on leaves, limits the germination and penetration of fungal diseases in the soybean plants. This happens because of an excess of water, as it is no longer necessary to continue the infection process in the host, since the fungus can obtain water from the host itself in the colonization stage (Huber and Itier, 1990). Moreover, in the case of Asian rust, genetic mutations may occur, with individuals capable of adapting to the most diverse climatic conditions, chemical fungicides, and technological levels of agriculture production (Juliatti et al., 2017). The infection in field occurs when the right amount of leaf dew is the driving force to increase disease intensity. Even with constant periods of rain, the necessary moisture for rust uredinospore germination and spread could not be achieved. So, the right periods of time in a day with dew, is probably the most important source of free water for fungal penetration and development on host tissue (Bromfield, 1984; Melching et al., 1989; Bonde et al., 2012). Del Ponte et al. (2006) observed that greater leaf wetness period increases ASR disease severity. Phakopsora pachyrhizi is a biotrophic parasite; it can survive duringdry months under unfavorable conditions, in alternative hosts such as kudzu (Pueraria spp.) and can penetrate directly through the cuticle and epidermis, facilitating infection (Zambedetti et al., 2007; Bradley et al., 2010).

The temperature in this binomial interaction with wetness, also directly influences the metabolic stages of the pathogen life cycle, since when there is an optimal temperature the pathogen can perform its metabolic functions with minimal stress (Bonde et al., 2007; Dias et al., 2005). A favorable range of temperature heavily influences different levels of disease intensity over time on different cultivars or susceptible plants like one of the alternative hosts of soybean rust the kudzu of the Pueraria genus (Bonde et al., 2009). But for soybean, the processes of spore germination, infection, latent period, lesion expansion and sporulation are related to a range of temperatures between 12 to $25^{\circ} \mathrm{C}$ with air relative humidity between 70 and $80 \%$. Also, high temperatures reached during daylight do not inhibit fungus development (Marchetti et al., 1976; Melching et al., 1989). Marchetti et al. (1975) determined that once the infection is established within the optimum range of temperature, the pathogen was able to 
colonize leaf tissue, even at a temperature of $30^{\circ} \mathrm{C}$, whichis usually reported to be lethal to the infectious process. However, in this temperature the incubation and latency periods were 6 and 12 days, respectively, compared to 4 and 9 days when colonization occurred under the optimal temperature of $23^{\circ} \mathrm{C}$.

Other authors describe this binomial interaction (temperature x wetting period) with $P$. pachyrhizi infection, reporting optimal temperature averages ranges between $20-25^{\circ} \mathrm{C}$, followed always by greater periods of leaf wetting produced lower latent and incubation periods in different cultivars and genotypes (Kochman, 1979; Casey, 1980; Vale, 1985; Sinclair and Backman, 1989; Alves et al., 2007; Bonde et al., 2012). The interaction between pathogen and host will lead to the appearance of the typical lesion of the disease and the various events that occur between deposition and the formation of new urediniospores constitute a single cycle of infection, or the monocycle. Melching et al. (1989) studying duration, frequency and temperature of different wetting periods regimes determined that no rust lesions were formed on leaves of the soybean cultivar Wayne at temperatures lower than $9^{\circ} \mathrm{C}$ and above $28.5^{\circ} \mathrm{C}$ even with a 16 hours of dew period. They also stated that a period of 6 to 7 hours of continuous leaf wetting were required for rust lesions to develop between 18 to $26.5^{\circ} \mathrm{C}$. At least six hours of moisture is required for infection to occur at $24^{\circ} \mathrm{C}$ in Japan (Kitani et al., 1960), from experiments in South Africa, no rust infection was found when incubating inoculated plants at temperatures below 15 or greater than $30^{\circ} \mathrm{C}$ (Caldwell et al., 2005). Kochman (1979) found that a 17 to $27^{\circ} \mathrm{C}$ temperature regime was clearly more favorable for rust infection during 16 hours of dew. The entry of the pathogen in the United States, was discussed by Pivonia and Yang (2006), they pointed out that in the United States, the occurrence of lower temperatures in the months of May through June limit the development of the disease in the South, which causes delay in the establishment of the epidemic in the North. In Brazil, the main soybean producing regions present favorable climatic conditions for the survival and the infectious process of the pathogen year-round. Since Brazil is one of the biggest soybean producers in the world and for its inherent tropical morphoclimatic characteristic, diseases of fungi etiology like the Asian rust, have the perfect environment to survive and maintain its life cycle all year round.

Literature supports that disease intensity, incubation and latent periods may be associated to host characteristics and achievement of partial resistance under different environmental conditions could be hard to be quantified (Bromfield, 1976; Parlevliet, 1997). These factors are determinant for the success of the wide geographical distribution, directly influencing the severity of the disease, causing great economic losses (Wrather et al., 2001). A series of field trials were conducted by Tschanz and Wang (1985) to obtain disease progress curves under different environmental conditions. The authors concluded that ASR resistance was influenced by environmental factors or physiological effects. This fact was confirmed in other rust severity assessment, when instability of the rust severity was displayed by some parental soybean lines (Pierozzi et al., 2008). In greenhouse and growing chambers, it was determined that the minimum period of leaf wetness for greater infection in soybean leaflets is 6 hours at the temperature range between 15 and $27.5^{\circ} \mathrm{C}$ for the cultivars Conquista, Savana and Suprema (Alves et al., 2007). Temperatures above $30^{\circ} \mathrm{C}$ and below $15^{\circ} \mathrm{C}$ had reduced disease progress levels also the minimum latent period was 6 days for the cultivar Conquista, and 9 days for the cultivars Savana and Suprema at a range of 15 to $25^{\circ} \mathrm{C}$. Bonde et al. (2012) studying two scenarios of environment combined effects, determined that temperatures higher than $35^{\circ} \mathrm{C}$ and subsequent dew period had significant reduction of rust lesions on the susceptible American cultivar Williams 82 . They also concluded that extreme lower temperatures below $18^{\circ} \mathrm{C}$ for short periods can account for observed absence or delay of soybean rust development in the southeastern United States. Souza and Fernandes (2008) evaluating the influence of leaf wetness 
in rust progression during 30 days on two soybean cultivars the Monsoy $8008 \mathrm{RR}$ and Conquista under greenhouse conditions, found that that there was no significant interaction between period of leaf wetting and genotypes and reported that 30 hours of wetting period provided the highest number of pustules and lesions. Danelli and Reis (2016) determined at 10 and $30^{\circ} \mathrm{C}$, no rust leaf infection for soybean cultivars BRSGO 7560 and BRS $246 \mathrm{RR}$ and related the occurrence in temperatures between 22 and $25^{\circ} \mathrm{C}$ the largest number of spores, lesions and uredinias per lesion. Also, the statistical analysis showed differences when both cultivars were compared regarding spore number and lesions, with the BRS 246 RR showing the highest values, while BRSGO 7560 showed the lowest values. The authors concluded that the cultivar BRSGO 7560 carries a Rpp gene that confers vertical resistance to soybean rust, this explained the lower values of disease intensity from the material derivative from American ascensions. Zambenedetti et al. (2007) obtained in its monocycle study that the BRS 134 and BRS 231 with an early cycle had higher AUDPC than the PI 459025 an America cultivar with the Rpp4 resistance gene. Vale et al (1990) studying the effect of temperature and duration of leaf wetness on P. pachyrhizi infection in the Paraná cultivar, obtained no infection on all wetting regimes of the temperatures of 12 and $28^{\circ} \mathrm{C}$. They also observed the maximum number of lesions. $\mathrm{cm}^{-2}$ on the inoculated leaves under a temperature of $20^{\circ} \mathrm{C}$ and at least 16 hours of leaf wetness, they also concluded this to be the optimal conditions to P. pachyrhizi infection. The climate conditions reached in their experiment had an average of $24.4^{\circ} \mathrm{C}$ and relative air humidity of $69 \%$. These variables were also used to model, simulate, and predict Asian rust by other authors using cultivars adapted to their countries (Pivonia and Yang, 2004; Reis et al., 2004). These monocycle studies of weather effects and plant resistance expression are important to estimate the potential disease occurrence and formulate strategies to control before the epidemics begins in vulnerable geographic regions and help farmers increase yield (Bromfield, 1976; Parlevliet, 1997; Leite and Amorim, 2002; Uchôa et al., 2012). In view of the above, we examined the behavior of genotypes of LAGER-UFU (Breeding Program from Germplasm Laboratory in University Federal of Uberlândia-Brazil), with partial resistance against ASR, as a function of different temperatures and leaf wetness duration.

\section{MATERIAL AND METHODS}

\section{Experimental information and genotypes}

The experiment was conducted at the Department of Plant Pathology of the Federal University of Lavras, Minas Gerais State, Brazil. We used growth chambers of the Sector of Plant Epidemiology. The seeds from genotypes were sown in foam trays with 60 cells with organic substrate $(10 \mathrm{~cm}$ length $\mathrm{x} 10 \mathrm{~cm}$ wide each) inside climate controlled chambers and humidity (humid chamber with a plastic dome) during a 50-day period (12-hour photoperiod). The experimental design consisted of a three-way factorial classification with seven genotypes interacting with two fixed effects, five temperatures $(18,21,24,27$ and $\left.30^{\circ} \mathrm{C}\right)$ and four-leaf wetting periods $(0,6,12$ and 24 hours) based on recommendations by Zambolim and Chaves (1990). Each replicate was composed of one plant per cell on the tray. The genetic material, consisted of six promising soybean genotypes developed by the LAGER / UFU improvement program (Table 1), based in Gloria Farm localized in Uberlândia City, Minas Gerais state and one more variety considered susceptible to rust, the DESAFIO RR - 8473RSF. These genotypes had partial resistance (low disease severity underfield conditions), good agronomic traits in field trials for P. pachyrhizi (Martins et al., 
2007; Silva et al., 2007; Martins and Juliatti, 2014). Some genotypes showed resistance (reduction of reproduction factor) under greenhouse conditions to race 3 of Heterodera glycines (Juliatti et al., 2017). The seeds of the F8 generation (after 10 years in a Breeding Program of LAGER-UFU (Germplasm Laboratory-University Federal of Uberlândia, MG)under field conditions were taken from pods of their respective genotypes, during the season 2014/2015. Each lineage was characterized depending on its field rust resistance response and classified according to their cycle (days) and degree of relative maturity (early maturity groups between 6 and 7). The genotypes selected for trial, presented approximately the same cycle (110 to 120 days).

Table 1. Soybean genotypes used in the assays with different disease severity and partial resistance levels, from the breeding program LAGER / UFU, after 10 years of experiments underfield conditions.

\begin{tabular}{lllll}
\hline \multirow{2}{*}{$\begin{array}{l}\text { Genotype } \\
\text { Code }\end{array}$} & $\begin{array}{l}\text { Lager-UFU } \\
\text { Code }\end{array}$ & Variety and Field Crossings & Temperature ${ }^{\circ} \mathbf{C}$ & $\begin{array}{l}\text { Leaf Wetting } \\
\text { (hours) }\end{array}$ \\
\hline 1 & L200 & Desafio 8473SRF Susceptible & & \\
2 & Check & & \\
3 & L266 & F8 BRSGO Luziânia X Potenza & & 0 \\
4 & L144 & F8 BRSGO Caiapônia X Potenza & & 6 \\
5 & L279 & F8 BRSGO Caiapônia X IAC100 & 18 & 12 \\
6 & L254 & F8 BRSGO Caiapônia X Potenza & 21 & 24 \\
7 & L218 & F8 BRSGO Luziânia X Potenza & 24 & 27 \\
\hline
\end{tabular}

Seeds were sown in trays that contained $1.6 \mathrm{~kg}$ of a substrate composed of sphagnum (70\%), roasted rice straw $(20 \%)$ and per liter $(10 \%)$ with balanced soluble macro and micronutrients $(\mathrm{N}, \mathrm{P}, \mathrm{K}, \mathrm{Ca}, \mathrm{MG}, \mathrm{S}, \mathrm{Zn}, \mathrm{Cu}$ and $\mathrm{B}$ ) applied to the soil (Hoagland and Arnon, 1950). Thinning was carried out 10 days after sowing them, leaving only one plant per cell, which was the experimental plot. The plants were kept in a greenhouse until the vegetative stage $\mathrm{V} 3$; then they were transferred to their respective constant temperature chambers of $18,21,24,27$ and $30^{\circ} \mathrm{C}$ with a photoperiod of $12 \mathrm{~h}$ until the end of the experiment.

\section{Inoculation and leaf wetness}

P. pachyrhizi uredinio spores present in fresh leafy uredinia serum, were collected from a field nursery plot with the cultivar Desafio 8473SRF.The suspension was prepared with distilled water containing $0.01 \%$ Tween 20 (v:v) and calibrated in a Neubauer chamber for a final concentration of $8.0 \times 10^{4}$ urediniospores.ml ${ }^{-1}$. After 7 days of plant acclimatization inside their respective temperature's chambers, the inoculum suspension was uniformly sprayed on both sides of the leaves. Immediately after inoculation, the plants were incubated in dark inside the climatic chamber during the duration of the leaf wetting period. All the leaf wetness periods $(6,12$ and 24 hours), except the 0 -hour treatment, had the moist chamber $(\sim 100 \%$ of air humidity) simulated by a sealed environment. This simulation consisted in the placement of trays containing inoculated plants, under transparent plastic bags previously moistened to create an atmosphere rich in water vapor. 
The irrigations were carried out by depositing water directly on the base of a plant's stem. The plants were then submitted to different leaf wetness periods of $0,6,12$ and 24 hours. After the removal of the last plastic bags of the 24-hour moisture period, the humidity in the air-conditioned chambers were maintained in $85 \pm 10 \%$ with fog nebulizers.

\section{Disease assessment}

Four severity assessments were performed on the central leaflet of all the trifoliate leaves in each plant. The severity was measured after training with a diagrammatic scale developed by Godoy et al. (2006), until the last day of evaluation (45 days). These data were integrated into the area under the disease progress curve (AUDPC), that was calculated in according to Shanner and Finey (1977). This AUDPC data was then subjected to analysis of variance between three factors, seven genotypes/cultivar, temperature and Leaf Wetness duration (LWD). When significative differences were obtained, surface response graphs were generated between the evolution of AUDPC in the binomial response for each genotype/cultivar. The incubation curve was calculated as a regression in function of the elapsed time, in days, between inoculation and evolution of severity at the five temperatures $\left(18,21,24,27\right.$ and $\left.30^{\circ} \mathrm{C}\right)$ for each genotype/cultivar. Also, to explain the appearance of the first signs of disease in the predicted incubation curves. One last assessment was made, it consisted in the registration of the day that the first signal of disease incidence appeared in any of the genotypes inoculated leaves submitted at different temperatures. This data was performed from the inoculation and continued every five days until the end of the experiment ( 9 evaluations in total).

\section{Statistical analysis}

The data obtained at each assay were submitted to the Shapiro-Wilk test to evaluate the assumptions of the analysis of variance. The data that obtained a normal distribution, were submitted to analysis of variance ( $F$ test). If $F$ test was significant, the results of the surface response with AUDPC in the binomial and incubation period with severity at different temperatures were used to generate a response surface for the first and polynomial regression curves for the second. For the surface response, AUDPC data in the binomial interaction, was fitted to 3D regressions (Plane, Paraboloid, Gaussian and Lorentzian). For incubation, disease severity data at different temperatures, were fitted to the polynomial regressions (linear, quadratic and cubic). The model that gave the highest coefficient of determination $\left(\mathrm{R}^{2}\right)$, low residual means square (RMS) and best fit residual plot distribution, was selected as the most appropriate model for describing the temporal pattern of the disease (Madden, 2007). All analysis of variance, regression and AUDPC data were performed using the R software (R Core Team, 2017) with the add-on packages ExpDes (Ferreira et al., 2003) and agricolae (Mendiburu, 2005). The surface response graph was generated by the Sigma Plot® 12.0 program.

\section{RESULTS AND DISCUSSION}

\section{Binomial and surface response of AUDPC}


There was significant AUDPC differences and interaction $(\mathrm{p}<0.001)$ between temperature, leaf wetness period and tested genotypes (Figure 1).The genotypes 5, 7 and the susceptible check, had the highest values for AUDPC, genotypes 4 and 6 had relative lower values, but still presented susceptibility in comparison with the genotypes 2 and 3 , which had the lowest values of disease, these traits could be indicative of partial resistance. In general, the highest AUDPC values (60 to 200) were showed in the temperature range of 22 to $26^{\circ} \mathrm{C}$ with above 10 hours of leaf wetting. At all temperatures, except 18 and $30^{\circ} \mathrm{C}$, it was possible to observe symptoms or signals, however, the highest AUDPC was observed at the temperature of $24^{\circ} \mathrm{C}$ for all genotypes. At temperatures of 21 and $27^{\circ} \mathrm{C}$ the AUDPC between 10 to 60 , lower values in comparison with the range of 22 to $26^{\circ} \mathrm{C}$. The period without prolonged leaf wetting $(0$ hours), showed the lowest AUDPC ( 0 to 50) for all temperature ranges, also were the conditions with dimmed symptoms and signals appearance.
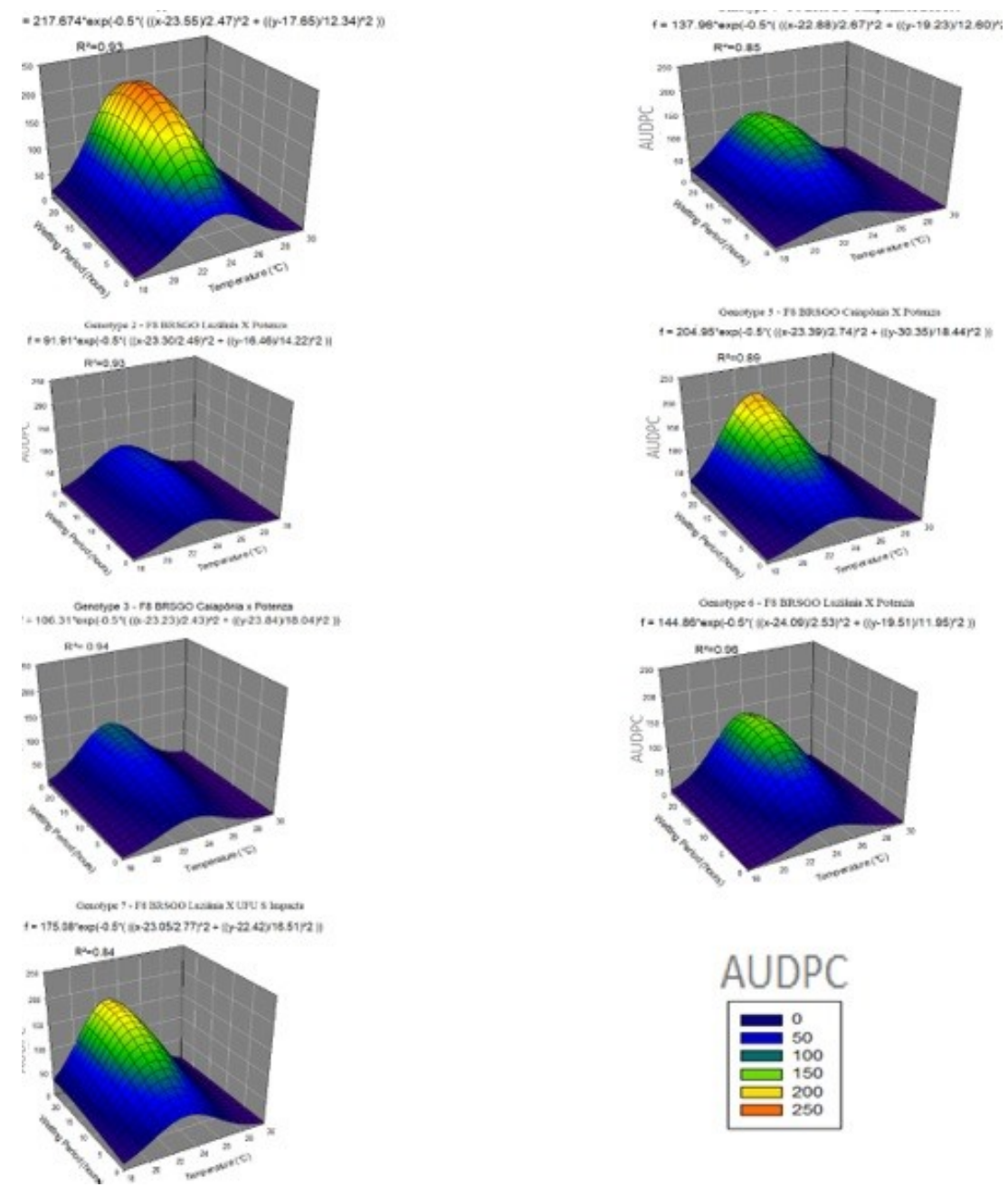

Figure 1. Gaussian models of response surface of P. pachyrhizi AUDPC in soybean genotypes, as a function of the temperature and duration of the leaf wetting period, described by the function, where $\mathrm{Z}$ is the AUDPC, $\mathrm{x}$ is the temperature and $\mathrm{y}$ is the duration of the leaf wetting period. 


\section{Incubation period}

During the 50 days of experiment (02/04/2017 - 04/05/2017) the first signals of rust appeared at, 15 DAI in the susceptible cultivar Desafio 8473SRF, 10 DAI in genotypes 4, 5 and 7, 20 DAI in genotypes 2 and 6 and $25 \mathrm{~s}$ in genotype 3. The ANOVAs results indicated significant severity differences $(\mathrm{P}<0.001)$ between inoculated genotypes and interaction when those were submitted at different temperature regimes, during the period of experimental assessment. After this analysis, we modeled an estimation of disease incubation period with severity in function of temperature (Figure 2) and compared to the day that the first incidence of ASR was observed. After 10 days of ASR uredinospores inoculation, at the temperature regime of $21{ }^{\circ} \mathrm{C}$ the first symptoms started to appear on genotypes 4,5 and 7 at 15 days on the susceptible cultivar (genotype 1) and 20 days in genotypes 2 and 6 and 25 days in genotype 3 .
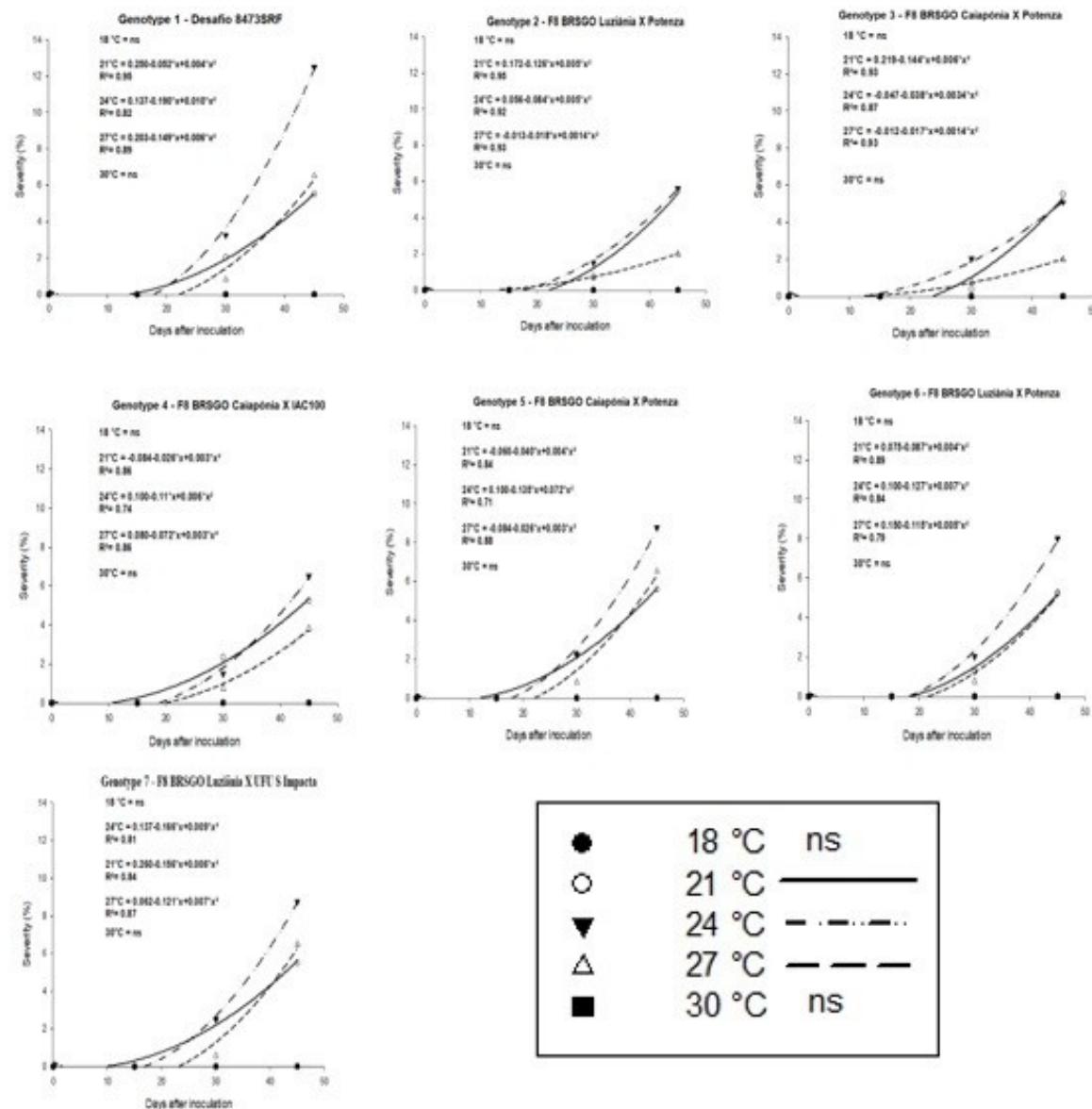

Figure 2. $P$. pachyrhizi incubation period in soybean genotypes at the temperatures of $1821,24,27$ and $30^{\circ} \mathrm{C}$.

At 15 days of inoculation in the temperature regime of $24^{\circ} \mathrm{C}$, genotypes 2,3 and 7 showed the first signals of rust, the other genotypes only presented the first signals after 20 
days of inoculation. At $27^{\circ} \mathrm{C}$ the signals of rust, appeared later in the inoculated leaves in comparison with other temperature regimes. Only after 25 days of inoculation, the signals appeared on genotypes 1,5 and 7 and in 20 days on genotypes 2, 3, 4 and 6 . No signals/symptoms of rust were observed in the genotype's leaves submitted at constant temperatures of 18 and $30^{\circ} \mathrm{C}$ during the 50 days of assay. In general, when the inoculated genotypes were submitted to higher temperatures like 24 and $27^{\circ} \mathrm{C}$, the signals started to appear at least 5 days later in comparison with the lowest temperature employed who showed results $\left(21^{\circ} \mathrm{C}\right)$. But for genotypes 2 and 3 the signals on the lower temperature $\left(21^{\circ} \mathrm{C}\right)$ only appeared at a later period in comparison with the temperatures of 24 and $27^{\circ} \mathrm{C}$, resulting in an inversion of results. About the severity levels, in general the highest values (\%) were obtained when the inoculated genotypes were submitted at a constant temperature of $24^{\circ} \mathrm{C}$ being later followed by $21^{\circ} \mathrm{C}$ and for last at the constant temperature of $27^{\circ} \mathrm{C}$. We can observe in the quadratic regressions, the inoculated check Desafio 8473SRF obtained the highest average value of severity $(12 \%)$ at the temperature of $24^{\circ} \mathrm{C}$, it also showed the highest curve slope growth during the 50 days of experiment. The genotypes 2,3 and 4 , could be highlighted and related to have partial resistance, since after the inoculation of these genotype plants, they showed lower average severity levels during the 50 days of experiment. Genotypes 2 and 3 at temperature of $27^{\circ} \mathrm{C}$ reached only $2 \%$ of average severity between plants and genotype 4 obtained the double (4\%) but still a lower value in comparison with other genotypes. At temperatures of 21 and $24^{\circ} \mathrm{C}$ the three genotypes obtained similar maximum average severity levels $(\sim 6 \%)$. We can conclude that when the inoculated genotypes were submitted to conditions with temperatures of 21 and $27^{\circ} \mathrm{C}$, they presented lower average values of disease severity and later appearance of symptoms or signals $20 \mathrm{DAI})$. The minimal average severity value was $2 \%$ for genotypes 2 and 3 at a constant temperature of $27^{\circ} \mathrm{C}$ and the maximum of $12 \%$ was resulted on the inoculated check plants submitted to a constant temperature of $24^{\circ} \mathrm{C}$. As related to the previous data, the $P$. pachyrhizi provoked minor infection and growth when influence under of 21 and $27^{\circ} \mathrm{C}$ in comparison with the constant temperature of $24^{\circ} \mathrm{C}$.

\section{DISCUSSION}

\section{Binomial and surface response of AUDPC}

Several epidemiological studies have been developed to correlate disease components with climatic variables and productivity, to provide ancillary information to prediction and damage models. Most of the authors that related the binomial interacting with different cultivars and genotypes in relation to Asian soybean rust progression, proposed the hypothesis that the differences in disease intensity, incubation and latent periods may be associated to host characteristics. But, few of them proved and added up the influence of genetic resistance in these equations (Kochman, 1979; Casey, 1980; Vale, 1985; Sinclair and Backman, 1989; Yang et al, 1991; Hartman, Wang and Tschanz, 1991; Reis et al., 2004; Juliatti et al., 2005; Del Ponte et al., 2006; Zambenedetti, 2007; Alves et al., 2007; Pierozzi et al., 2008; Bonde et al., 2012).

We focused on the characterization of genetic resistance in detriment of changes in a binomial composed by leaf wetness duration and temperature. The highest AUDPC values were presented in the temperature range of 22 to $26^{\circ} \mathrm{C}$ with above 10 hours of leaf wetting, 
reaching the highest value (185) in the susceptible cultivar Desafio 8473SRF at the temperature of $24^{\circ} \mathrm{C}$. When the genotypes were submitted at 18 and $30^{\circ} \mathrm{C}$ no signals or symptoms were observed. The genotypes plants without prolonged leaf wetting ( 0 hours), had the lowest AUDPC (0 to 50) and higher latent periods within all temperature ranges. In the literature, most of the results with this binomial influencing $P$. pachyrhizi infection matched to ours. Most of these studies indicated temperature averages between 20 to $25^{\circ} \mathrm{C}$ always followed by greater periods of leaf wetting reproducing higher severity levels, lower latent and incubation periods in different cultivars and genotypes (Kochman, 1979; Casey, 1980; Vale, 1985; Sinclair and Backman, 1989; Alves et al., 2007; Bonde et al., 2012). Marchetti et al. (1976) and Melching et al. (1989) when studying the effect of the temperature and leaf wetness duration (LWD), on germination and infection by urediniospores of P.pachyrhizi, the fungus had an optimal germinate range of 15 to $26.5^{\circ} \mathrm{C}$ and maximum infection rate; severity occurred between 10 to 12 hours of leaf wetting period. They also related that susceptible soybean varieties, when inoculated did not show symptoms of rust under LWD than six hours and higher temperatures of $27^{\circ} \mathrm{C}$.

In the literature, several authors descripted different levels of ASR severity in different cultivars at similar environmental conditions. Kitani and Inoue (1960) indicated that least six hours of moisture is required for infection to occur at $24^{\circ} \mathrm{C}$ in a Japanese soybean cultivar. This temperature is inside the range of 17 to $27^{\circ} \mathrm{C}$, described in the experiment with ASR inoculation on the susceptible cultivar wills made by Kochman in Australia in 1979. The author also reported that ASR infection was clearly more favorable when this temperature range was linked of 16 hours of continuous dew. More recently Vale et al. (1990) studying the effect of temperature and duration of leaf wetness on $P$. pachyrhizi infection in the cultivar Paraná (susceptible to ASR), obtained no infection on all LWD of the temperatures of 12 and $28^{\circ} \mathrm{C}$. They also observed the maximum number of lesions $\mathrm{cm}^{-2}$ on the inoculated leaves under a temperature of $20^{\circ} \mathrm{C}$ and at least 16 hours of leaf wetness. In South Africa Caldwell et al. (2005) related no rust infection was found when inoculated plants were incubated at temperatures below $15^{\circ} \mathrm{C}$ or greater than $30^{\circ} \mathrm{C}$. Nunkumar et al. (2005) studying the influence of temperature, relative humidity $(\mathrm{RH})$ and moisture period (MP) in the number of pustules and lesions of ASR in the highly susceptible soybean cultivar LS5995 determined that the highest number of pustules per lesion occurred at $21-24^{\circ} \mathrm{C}$. The authors also stated that ASR infection can occur after at least six hours of moisture period but for a higher probability to a successful infection the plants need to be exposed at least to $16 \mathrm{~h}$. Infection in they work did not occur on plants incubated at $15^{\circ} \mathrm{C}$ and $30^{\circ} \mathrm{C}$ in any moisture period. Alves et al. (2007) determined that the minimum period of leaf wetness for greater infection in soybean leaflets is 6 hours at the temperature range between 15 and $27.5^{\circ} \mathrm{C}$ for the cultivars Conquista, Savana and Suprema. These authors also demonstrated a similar result to ours, demonstrating that temperatures above $30^{\circ} \mathrm{C}$ and below $15^{\circ} \mathrm{C}$ had reduced disease levels. The increasing LWD on the inoculated genotypes tested in our work, resulted in higher disease intensity and levels of AUDPC. Junior and Fernandes (2010) related that longer leaf wetness periods increased the severity of soybean rust, and number of necrotic lesions in cultivars MSOY 8008 RR and Conquista, both are considered with different levels of reaction to the disease. Working with the previous cultivars Souza and Fernandes (2008), evaluating the influence of leaf wetness in AUDPC levels during 30 days of experiment under greenhouse conditions, they found that no significant differences between both and leaf wetness. They also reported that 30 
hours of wetting period provided the highest number of pustules and lesions. We can ensure that inoculated soybean plants, under longer leaf wetness periods, end up developing higher levels of ASR. Danelli and Reis (2016) determined at 10 and $30^{\circ} \mathrm{C}$, no rust leaf infection was detected. Also, the largest number of uredinospores, lesions and uredinias per lesion was obtained in temperatures between 22 and $25^{\circ} \mathrm{C}$ for soybean cultivars BRSGO 7560 (resistant) and BRS $246 \mathrm{RR}$ (susceptible). There were also significant differences for number of spores produced, where the resistant cultivar reached lower levels of uredinospores (3000 and 8000 per $\mathrm{cm}^{2}$ ) and uredinias per lesion (8 to 13). The authors concluded that the cultivar BRSGO 7560 carries a Rpp gene that confers vertical resistance to soybean rust, this explained the lower values of disease intensity from the material derivative from American ascensions.

When we contrast the influence of temperature in fungi development, there is a consensus among authors that temperatures below $15^{\circ} \mathrm{C}$ are not suitable to rust development, but in our work, no signals or symptoms were observed when the inoculated plants were submitted to a constant temperature of $18^{\circ} \mathrm{C}$. Also, the lower disease levels results achieved at temperatures greater than $27^{\circ} \mathrm{C}$ matched with other results in the literature. The processes of spore germination, infection, latent period, lesion expansion and sporulation are related to a range of temperatures between 15 to $25^{\circ} \mathrm{C}$ with air relative humidity between 70 and $80 \%$. Some authors stated that high temperatures reached during daylight do not inhibit fungus development (Marchetti, et al., 1975; Melching et al., 1989). The same authors discussed that once the infection was established within the optimum range of temperature, the pathogen was able to colonize leaf tissue, even at a temperature of $30^{\circ} \mathrm{C}$. This temperature is usually reported to be lethal to the infectious process. In the end we can infer that temperature in this binomial interaction, influences the transitions of pathogen metabolic stages in their life cycle. And when an optimal temperature is present on the environment, the pathogen can perform their metabolic functions with minimal stress during the infection (Dias et al., 2005; Bonde et al., 2007). Moreover, in the case of ASR, genetic mutations may occur, with individuals capable of adapting to different hosts biology, diverse climatic conditions, chemical products, and technological levels of agriculture production (Juliatti et al., 2017). P. pachyrhizi spores that encounters favorable environmental conditions with an optimum range of temperature, regular leaf wetness periods and susceptible host, rust has higher chances to survive and restart its polycycle (Bonde et al., 2009). The interaction between temperature and increasing leaf wetness duration, creates a synergism that will reflects in better condition for fungal infection and spread in host tissues and consequently will reflect in higher AUDPC values. If we add up a third factor associated to the host components like resistance genes that contributes to biochemical responses (enzymes like PAL, POX) and constitutive barriers (cell wall and lignin), the disease levels differences become greater and wider.

The entry of the pathogen in the United States, was discussed by Pivonia and Yang (2006), they pointed out that in the United States, the minimal temperature threshold to stress ASR and prejudice the survivor of a population between two infections, is the maintenance of temperatures below $11^{\circ} \mathrm{C}$ through 9 to 10 weeks. This limits the development of the disease in the South during the months of May through June, which causes delay in the establishment of the epidemic in the North. In an experiment made on highlands and mountains regions found in the Brazilian states of Rio Grande do Sul and Santa Catarina, Gallotti and Casa (2012) described that soybean volunteer plants found on 
the field between harvest seasons, did not host ASR. They explained that lower temperatures $\left(0\right.$ to $\left.5^{\circ} \mathrm{C}\right)$ on the on months of June and July in the North Plateau and the Serrano Plateau, kill or under develop most of the majority of volunteer soybean plants and dim the chances of uredinospore infection and survivor in leaf tissues. This situation could be related to the ones found by the lower risk of ASR epidemics in the beginning of the soybean season at the north states localized in US. But this region in Brazil is an exception, they are localized under temperate climatic conditions. The main soybean producing regions present tropical and favorable climatic conditions for the maintenance of the infectious process of the pathogen year-round.

In the experiment, genotypes 5, 7 and the susceptible cultivar Desafio 8473SRF obtained the highest values for AUDPC, genotypes 2 and 3 otherwise presented the lowest AUDPC values during trial conduction. We can establish here evidence of presence of different levels of resistance or more particularly partial resistance expression. These genotypes also can be inserted as important sources of resistance to breed future soybean cultivars with good potential of yield, shorter cycle (110-120 days) and stable resistance (Martins et al., 2007, Silva et al., 2007; Martins and Juliatti, 2014). These variables are important to adopt the right management of the continuous ASR reproduction cycles (generating higher AUDPC) under favorable conditions of temperature and LWD found in the tropics during the year. Brazil is the second biggest soybean producer in the world and for its inherent tropical morphoclimatic characteristic, diseases of fungi etiology like the Asian rust, has the perfect environment to survive and maintain its life cycle all year around. The resistance of soybean cultivars that contains major genes to rust can vary temporally and geographically (Kato and Yorinori, 2008; Akamatsu et al., 2013; Paul et al., 2013; Twizeyimana and Hartman, 2012; Walker et al., 2014). So, in this tropical climatic scenario with higher selection of rust pathotypes that are under intense exposition of fungicides compounds and cultivars with genes that confers vertical resistance, the adoption of a more stable resistance, like the partial resistance is a necessary measure to be inserted on disease management to help diminished the survival and progression of the ASR agent (Parlevliet, 1997).

\section{Incubation Period}

After the determination of AUDPC differences and interaction between genotypes in the binomial, we established the necessary time the fungus needs to incubate in those inoculated genotypes at different temperatures. The longer a fungus takes to incubate inside a host tissue, slower is their rate of growth and fewer cycles of reproduction are developed in a crop season (Jan and Gibson, 1998; Madden et al, 2007). Parlevliet (1983), Martins et al. (2007) and Vallavielle-Pope et al. (2000) stated that cultivars with incubation periods longer than 14 days could be classified as having partial resistance. Meanwhile, the first signals of rust in our experiment, appeared in the susceptible cultivar Desafio 8473SRF at $15 \mathrm{DAI}$, at 10 days in genotypes 4, 5 and 7, at $20 \mathrm{DAI}$ in genotypes 2 and 6 and 25 days in genotype 3. Between all temperature regimes adopted the first signals of rust started to appear sooner at the temperature of $21^{\circ} \mathrm{C}(10 \mathrm{DAI})$ and in a later period on $27^{\circ} \mathrm{C}(25$ DAI).In general, when the inoculated genotypes were submitted to higher temperatures such as 24 and $27^{\circ} \mathrm{C}$, the signals started to appear at least five days later in comparison with the lowest temperature employed who showed results $\left(21^{\circ} \mathrm{C}\right)$. Our results demonstrate that there 
is a wide range in values of disease and latent periods, when the inoculated genotypes and cultivars were submitted under different climatic conditions (binomial). Zambenedetti et al. (2007) working with monocycle and complete resistance related that cultivars BRS 134 and BRS 231 even with early cycle, had higher AUDPC than the PI 459025, an America cultivar with the Rpp4 resistance gene. In this work, the considered susceptible cultivars BRS 231 and FT-2 took nine days to suffer the first signals of rust and the PI 459025 with a complete resistance gene Rpp4, resulted in twelve days of latency. A small gap in days between the material results, but interesting for disease reduction whereas thinking reduction of pathogen cycles of spore production. Melching et al. (1989), who studied the duration, frequency and temperature of different wetting periods regimes determined that no rust lesions were formed on leaves of the soybean cultivar Wayne in temperatures lower than $9^{\circ} \mathrm{C}$ and above $28.5^{\circ} \mathrm{C}$ even with a 16 hours of dew period. They also stated that a period of 6 to 7 hours of continuous leaf wetting were required for rust lesions to develop between 18 to $26.5^{\circ} \mathrm{C}$. They used different isolates in the cultivar Wayne from Taiwan, India, Australia, and they obtained lesions from six to seven days after inoculation. Also, an average of 8 to 14 uredinia per lesion, was showed after seven weeks of experiment in $24.5^{\circ} \mathrm{C}$ and $55 \%$ relative humidity. Marchetti et al (1975) determined that once the infection was established at $30^{\circ} \mathrm{C}$, the incubation and latency periods were 6 and 12 days, respectively, against 4 and 9 days when colonization occurred under the optimal temperature of $23^{\circ} \mathrm{C}$. Bonde et al. (2012) studying two scenarios of environment combined effects, determined that temperatures higher than $35^{\circ} \mathrm{C}$ and subsequent dew period had significant reduction of rust lesions on the susceptible Williams 82 (American cultivar). They also concluded that extreme lower temperatures below $18^{\circ} \mathrm{C}$ for short periods can account for observed absence or delay of soybean rust development in the southeastern United States. These results corroborate to explain the motive that countries within temperate climatic conditions usually have smoother and localized epidemics of ASR, instead to the ones within tropical latitudes. Alves et al. (2007) described the minimum rust latent period was 6 days for the cultivar Conquista, and 9 days for the cultivars Savana and Suprema in ta range he temperature of 15 to $25^{\circ} \mathrm{C}$. Vale et al. (1990), evaluating the soybean Paraná cultivar, observed the first symptoms after 9 and 12 days of inoculation at 20 and $24^{\circ} \mathrm{C}$ respectively. In average most of the studies pointed that the signals and symptoms of rust started to appear at least 6 to 12 days after inoculation, but in our work the lesions started to appear in average at least 15 days to 20 days after inoculation. These differences at the results could probably be related to inoculum variation. Also, the highest severity levels obtained by monocycle experiments ranged between $12-20 \%$, matching with the $12 \%$ showed by the cultivar Desafio RR 8473 RSF. Koga et al.(2008) quantifying resistance through latent period and severity progression, determined that genotypes BRS 124, BACURI, PI230970SH and PI224270-1 took in average 7.84 days to reach 50\% of the severity in comparison with the 11.91 days reached by genotypes ER046881 trough ER062164. They also stated that the parameter incubation period ranged from 3 to 6 days and was not important to differentiate the genotypes, since some of them appearance of lesions in dates was not consistent. In our experiment the incubation period results were consistent and different from their findings. The appearance of lesions in our results showed different levels of severity, allowing grouping of genotypes with different partial resistance reaction. 
The materials that showed desired partial resistance with higher latent period, lower severity and consequently lower AUDPC values are the results of the F8 crossings between the cultivars BRSGO Luziânia with Potenza (genotype 2), BRSGO Caiapônia with Potenza (genotype 3) and BRSGO Caiapônia X IAC100 (genotype 4). Juliatti et al. (2005), in a work with the cultivar UFUS Impacta, from hybridizations between the cultivars Cristalina and IAC 100, obtained partial resistance to P. pachyrhizi with low disease values. Oliveira and Juliatti (2017) obtained high yield and lower values of disease intensity from the materials derived from crossings between BRSGO Luziânia X UFUS Impacta, BRS Caiapônia X Potenza and BRSGO Caiapônia X IAC100. Santos et al. (2007) described the monocycle of genotypes derived by Cristalina and IAC 100 breeding. The results demonstrated that both sources provided genotypes with higher partial resistance to soybean rust, after 12 days of inoculation. Martins et al. (2007), when measuring the average incubation period in several soybean genotypes, verified that the genotypes provided by IAC 100 and Cristalina crosses, had a variation from 11.43 to 16.45 days. Parlevliet (1983) and Vallavielle-Pope et al. (2000) discussed that a single day increase in the establishment of parasitic relationships, is already a significant contribution to decrease the number of a fungus reproductive cycles in a crop (polycycle). Parlevliet (1997) defined genetic resistance as the as the host ability to prevent the growth and development of the pathogen and partial resistance is a characterization of the reduction in epidemic rates and increase on latent period. This reduction in rates causes a decrease in the population of the pathogen, and consequently a decline in the amount of inoculum and intensity of the disease (Wang and Hartman, 1992). This type of resistance became evident and important when a monogenic resistance is overcome by a new breed of pathogen (Parlevliet, 1997). Marchetti et al. (1975) concluded after analyzing the development of uredinia in tissues of Lee 68 and PI 200492, that slower lesion development, shorter period during the formation of new lesions and earlier senescence of rust lesions are variables related to partial resistance characterization and polygenic expression These characteristics contribute to the reduction in the amount of secondary inoculum, thus diminishing the potential for pathogen spread in the field polygenic resistance is characterized in function of the expression of constitutive barriers of horizontal resistance like lignin and cell wall thickness, genes expression and molecular changes due to different mechanisms of resistance (Luck et al., 2011).

Monogenic resistance instead confer resistance to a limited number of rust isolates, the specific resistance genes are quickly overcome, since the pathogen presents high genetic variability and although the occurrence of pathotypes denounces this characteristic, little is known about this variability (Bromfield et al., 1980; Bonde et al., 2006). Hartman et al (2004) also pointed out that fungus variability is the main factor in the breakdown of vertical resistance genes. The presence of multiple virulence genes in the pathogen and the absence of multiple resistance genes in the host confers a major competitive advantage to rust, reducing the expectation of using gene rotation or pyramiding as a measure for disease control, since the pathogen generally retains virulence genes that may or not be expressed in their life cycle (Tschanz et al., 1983; Hartman et al., 1997). Given the rapid breakdown of Rpps gene from 1 to 6 , there is a concern that the fungi are adapting and may have developed new specific resistance genes during the field season (Paul et al., 2013; Akamatsu, 2013; Kawashima et al., 2016). We can propose a future scenario of soybean with Rpp genes, cultivated during all year on tropical conditions (Paraguay and Bolivia) having a serious risk to suffer the "vertifolia effect", mostly because of pathogen variability 
under pression of selection by these major genes. The presence of multiple virulence genes in the pathogen and the absence of multiple resistance genes in the host confers a major competitive advantage to rust, reducing the expectation of using gene rotation or pyramiding as a measure for disease control, since the pathogen generally retains virulence genes that may or not be expressed in their life cycle (Hartman et al., 1997). Attached to this, another issue is coming to the surface, breeding programs who focus on materials with vertical resistance to rust, end up losing genes who confers horizontal. This problem occurs when breeders select in field plants under the protection of pesticides and several characteristics expressed by minor genes, that can possible be interesting ended up disappearing by the pesticide effect. So, in the face of a new virulent pathogen race, the plant resistance could be broken more easily if the plant does not express the minor genes effect(Van der Plank 1963; Parlevliet, 1983).

When a plant breeder seeks resistance to a given pathogen, he often crosses a cultivar with a resistance gene or line with a locally adapted that is not extremely susceptible to the pathogen. Is common to this parent possess variable levels of partial resistance, in fact cultivars or lines without any partial resistance are rare (Parlevliet and Kuiper, 1977; Parlevliet, 1978; Parlevliet et al., 1979; Niks, 1983). Since none of the known Rpp genes provides resistance against all isolates of P. pachyrhizi (Hartman et al. 2005) and the ability of ASR to overcome single-gene qualitative resistance has been reported (Hartman et al., 2005), development of durable "less-rusting" and "slow-rusting" cultivars is one of the options for breeding for resistance to soybean rust ( $\mathrm{Li}$ and Young 2009). A series of field trials were conducted in 1985 by Tschanz and Wang to obtain disease progress curves under different environmental conditions. The authors concluded that ASR resistance was influenced by environmental factors or physiological effects. This fact was confirmed in other rust severity assessment, when instability of the rust severity was displayed by some parental soybean lines (Pierozzi et al., 2008). After reports and confirmation cases of ASR resistance to the Rpp genes and groups of chemical fungicides, the alternative of partial resistant cultivars, is gaining importance in this scenario of uncertainties. Also, the producers environment is under constant change with weather conditions changing hourly and daily. In this presumable agricultural scenario, where higher costs, more time are involved in the development of new fungicide molecules to control ASR, and Rpp genes being break down we need start use tools like partial resistance in the management of ASR.

The greatest issues in the development of partial resistance is determine these shifts (days) of incubation, latent and sporulation periods at different environments and levels of technology (heavy use of fungicide spray). Monocycle studies can help to monitor climatic effects in plant resistance expression, likely the way as nutrient and soil conditions could affect plant growth during crop cycle. To estimate the potential disease occurrence and formulate strategies to control ASR epidemics, is important understand deeper how vulnerable these geographic regions (endemic), could express plant potential when there are under heavy inoculum source and climactic oriented conditions for rust growth (Bromfield, 1976; Parlevliet, 1997; Leite and Amorim, 2002; Uchôa et al., 2012). So, we must raise the probability of durable resistance considerably by concentrating on resistance that have lasted for a considerable time, with components of partial resistance that can be expressed with major or/and minor genes and avoiding genes that showed notorious short lifespan (Clifford, 1974; Parvlievet, 1979). When durable resistance is the goal in a breeding 
program it is a necessary to realize that there is no guarantee that the resistance selected for is indeed durable. Only time and exposure of these genes on a large-scale production can give us the definitive answer (Parlevliet, 1983). For cultivar development and yield improvement a durable and stable resistance like partial resistance can provide an economic and environmentally friendly way to protect soybean crops from the majority P. pachyrhizi pathotypes on different geographical regions. Danelli and Reis (2016) did the quantification of incubation, latent and infection periods of P.pachyrhizi in soybean, according to chronological time and degree-days. The results showed that the chronological time and degree-days can be used will study the classification the genotypes resistance index when the researcher will use germplasm with partial resistance. Del Ponte et al. (2008) showed that meteorological factors change the ASR epidemics, and the systems approach has implications for risk assessment. We can conclude that $P$. pachyrhizi infection is shifting to a greater incubation period and fast sporulation induction after uredinia formation. during the experiment. The genotypes 2 - F8 BRSGO Luziânia X Potenza, 3 - F8 BRSGO Caiapônia X Potenza and 4 - F8 BRSGO Caiapônia X IAC100 will be used in field conditions, with fungicides sprays reduction for the growers and reduction of the directional selection in the pathogen population. This strategy of management can avoid the emergency of new pathotypes and races with low sensitivity to specific fungicides (triazoles, strobilurins and carboxamides) (Juliatti et al., 2017).

\section{CONCLUSIONS}

There were differences among genotypes in AUDPC under the same temperature conditions and leaf wetness duration. No signals, lesions or symptoms of rust appeared at below $18^{\circ} \mathrm{C}$ and above $30^{\circ} \mathrm{C}$. The relationship between temperature and LWD affect the AUDPC and temperature affects incubation period. The highest AUDPC values occurred at $24^{\circ} \mathrm{C}$ and leaf wetting period of 24 hours, and the lowest values were achieved at temperatures greater than $27^{\circ} \mathrm{C}$.Cultivar Desafio RR $8473 \mathrm{RSF}$ showed susceptibility to ASR. ASR lesions started to appear onaverage at least $15 \mathrm{DAI}$ in partial resistant genotypes: F8 BRSGO Luziânia X Potenza, F8 BRSGO Caiapônia X Potenza and F8 BRSGO Caiapônia X IAC100,whihcalso had lower AUDPC and severity values, during the monocycle experiment. $P$. pachyrhizi infection is shifting to a longer incubation period and fast sporulation induction after uredinia formation. These genotypes can be used underfield conditions, with less need for fungicides helping avoid the emergence of new pathotypes with low sensitivity to fungicides.

\section{ACKNOWLEDGMENTS}

The authors thank the Federal University of Uberlândia (UFU), the Minas Gerais State Research Foundation (FAPEMIG), the National Council for Scientific and Technological Development (CNPq), and the Coordination for the Improvement of Higher Education Personnel (CAPES) for funding this research.

\section{CONFLICTS OF INTEREST}

The authors declare no conflict of interest. 


\section{REFERENCES}

Akamatsu H, Yamanaka N, Yamaoka, Y, Soares RM, et al. (2013). Pathogenic diversity of soybean rust in Argentina, Brazil, and Paraguay. J. of Gen. PlantPathol. 79: 28-40.

Alves MDEC, Pozza EA, Ferreira JB, Araújo DV, et al. (2007). Intensidade da ferrugem asiática (Phakopsora pachyrizi H. Sydow \& P. Sydow) da soja (Glycine max L.) Merr.) nas cultivares Conquista, Savana e Suprema sob diferentes temperaturas e períodos de molhamento foliar. Summa Phytopathol. 33: 239-244. doi: 10.1590/S010054052007000300005.

Bonde MR, Nester SE, Austin CN, Stone CL, et al. (2006). Evaluation of virulence of Phakopsora pachyrhizi and P. meibomiae isolates. Plant Dis. 90: 708-716.doi: 10.1094/PD-90-0708.

Bonde MR, Berner DK, Nester SE and Frederick RD (2007). Effects of temperature on urediniospore germination, germ tube growth, and initiation of infection in soybean by Phakopsora isolates. Phytopathology. 97: 997-1003. doi: 10.1094/PHYTO-97-8-0997.

Bonde MR, Nester SE, Moore WF and Allen TW (2009). Comparative susceptibility of kudzu accessions from the southeastern United States to infection byPhakopsora pachyrhizi. Plant Dis. 93: 593-598. doi: 10.1094/PDIS-93-60593.

Bonde MR, Nester SE and Berner DK (2012). Effects of soybean leaf and plant age on susceptibility to initiation of infection by Phakopsora pachyrhizi. Plant Health Prog. 13: 1.doi: 10.1094/PHP-2012-0227-01-RS.

Bradley C, Hines R, Haudenshield IS and Hartman GL (2010). First report of soybean rust, caused by Phakopsora pachyrhizi, on kudzu (Pueraria montanavar.lobata) in Illinois. Plant Dis. 94: 477. doi: 10.1094/PDIS-94-4-0477A.

Bromfield KR (1984). Soybean Rust - Monograph No. 11. Saint Paul MN. APS Press.

Bromfield KR (1976). World soybean rust situation. In: HILL, L. D. World Soybean Research: proceedings of the world soybean research conference. Danville: The Interstate Printers and Publishers, p.491-500.

Bromfield KR and Hartwig EE (1980). Resistance to soybean rust and mode of inheritance. Crop Sci. 20: 254-255. doi:10.2135/cropsci1980.0011183X002000020026x.

Bromfield KR and Melching JS (1982). Sources of specific resistance to soybean rust. Phytopathology. 72: 706.

Bromfield KR, Melching JS and Kingsolver CH (1980). Virulence and aggressiveness of Phakopsora pachyrhizi isolates causing soybean rust. Phytopathology. 70: 17-21. doi:101094/Phyto-70-17.

Caldwell PM, Nunkumar A, Pretorius ZA and Fernandes JMC (2005). Development of Phakopsora pachyrhizi at different temperatures, relative humidities and leaf wetness duration. In: International workshop on plant diseaseepidemiology, 9., Landerneau, Proceedings. Bordeaux: Societé Francaise dePhytopathologie.

Casey PS (1980). The epidemiology of soybean rust Phakopsora pachyrhizi Syd. Soybean Rust Newsl. 4(1): 3-5.

Clifford BC (1974). The choice of barley genotypes to differentiate races of Puccinia hordei Otth. Cereal Rusts Bull. 2(1): 5-6.

Danelli ALD and Reis EM (2016). Quantification of incubation, latent and infection periods of Phakopsora pachyrhizi in soybean, according to chronological time and degree-days. Summa. Phytopathol. 42: 11-17.doi: 10.1590/01005405/1920.

Dias MB, Pozza EA, Abreu MS and Miranda EO (2005). Efeito da temperaturanocrescimento micelial, produção e germinação de conídios de Colletotrichum spp.isolados de Coffea arabica L. Ciênc. Agrotec. 29: 545-552. doi: 10.1590/S1413- 70542005000300006.

Del Ponte E, Medeiros E and Esker PD (2008). Meteorological factors and Asian soybean rust epidemics: a systems approach and implications for risk assessment. Sci. Agric. 65: 88-97. https://doi.org/10.1590/S010390162008000700014.

Ferreira EB, Cavalcanti PP and Nogueira DA (2013). ExpDes.pt:Experimental Designs package (in Portuguese). FRAC.Monitoringresults and use recommendations available at [http://www.frac.info/working-group/sdhifungicides/general-use-recommendations] Accessed 04 September 2020.

Gallotti GJM and Casa RT (2012). Sobrevivência de Phakopsora pachyrhizi em plantas voluntárias de soja nas regiões do Planalto Norte e Planalto Serrano de Santa Catarina. Agropecuária Catarinense, Florianópolis, SC. 25(2): 64-67.

Godoy CV, Koga L and Canteri MG (2006). Diagrammatic scale for assessment of soybean rust severity. Fitopat. Bras. 31: 63-68.

Hartman GL, Wang TC and Tschanz AT (1991). Soybean rust development and the quantitativerelationship between rust severity and soybean yield. Plant Dis. 75: 596-600. doi: 10.1094/PD-75-0596.

Hartman GL, Wang TC and Shanmugasundaram S (1997). Soybean rust research:Progress and future prospects. In: World soybean research conference, 5. Bangkok. Proceedings. Bangkok: Kasetsart University Press. p. 180-186.

Hartman GL, Miles MR and Frederick RD (2005). Breeding for resistance to soybean rust. Plant Dis. 89: 664-666. doi: 10.1094/PD-89-0664.

Huber L and Irier B (1990). Leaf wetness duration in a field bean canopy. Agric. For. Meteorol. 51: 281-292.doi: 10.1016/0168-1923(90)90113-K.

Hoagland DR and Arnon DI (1950). The water culture method for growing plants without soils. Berkeley: California Agricultural Experimental Station, 1950 
Juliatti FC, Polizel AC, Balardin RS and Vale FXR (2005). Ferrugem da soja- Epidemiologia e manejo para uma doença reemergente. In: Luz WC, Fernandes JMC, Prestes AM, Picinini, EC.Rev. Anual de Patolologia de Plantas. 13: 351-395.

Juliatti FC, Polloni LC, Morais TP, Zacarias NRS, et al. (2017). Sensitivity of two isolates of Phakopsora pachyrhizi todithiocarmamate, chloronitril, triazoles, strobilurins, and carboxamides fungicides. Biosci. J. 33(4): 933-943. doi: 10.14393/BJ-v33n4a2017-38357.

Juliatti BCM, Beloti IF, Pena LC and Juliatti FC (2017). Soybean genotype analysis for cyst nematoderesistance. Genet. Mol. Res. 6: gmr16039705. doi: 10.4238/gmr16039705

Junior HBM and Fernandes JJ (2010). Período de molhamento foliar para ocorrência de ferrugem asiática (Phakopsora pachyrhizi) em dois cultivares de soja (Glycine max). Enciclop biosfera, Centro Científico Conhecer - Goiânia, 6(11): 11.

Kato M and Yorinori JT (2008). A study on a race composition of Phakopsora pachyrhizi in Brazil: a difficulty of race identification. JIRCAS Working Report. 58: 94-98.

Kawashima CG, Guimaraes GA, Nogueira SR, Maclean D, et al. (2016). et al.A pigeonpea gene confers resistance to Asian soybean rust in soybean. Nat. Biotechnol. 34: 661-665. doi: 10.1038/nbt.3554.

Kawuki RS, Tukamuhabwa P and Adipala E (2004). Soybean rust severity, rate of rust development, and tolerance as influenced by maturity period and season. Crop Prot. 23: 447-455. doi: 10.1016/j.cropro.2003.09.016.

Kitani K, Inoue Y and Natsume T (1960). Studies on soybean rust and its control. II. Studies on the control of soybean rust. Shikoku Nogyo Shikenjo Hokoku, Bull. Shikoku Natl. Agric.Exp. Stn. 5: 343-58.

Kochman JK (1979). The effect of temperature on development of soybean rust (Phakopsora pachyrhizi). Aust. J. Agric. Res. 30(2): 273-277. doi: 10.1071/AR9790273.

Koga LJ, Canteri MG, Calco ES, Unfried JR, et al. (2008). Análise multivariada dos componentes da resistência à ferrugem-asiática em genótipos de soja. Pesq. Agropec. Bras. 43: 1277-1286. doi: 10.1590/S0100204X2008001000004.

Leite RMVBC and Amorim L (2002). Influência da temperatura e do molhamento foliar no monociclo da mancha de Alternária em girassol. Fitopatol. Bras. 27: 193-200.doi: 10.1590/S0100-41582002000200012.

Li S and Young LD (2009). Evaluation of selected genotypes of soybean for resistance to Phakopsora pachyrhizi. PlantHealth Prog. doi: 10.1094/PHP-2009-0615-01-RS.

Luck J, Spackman M, Freeman A, Trebicki P, et al. (2010). Climate change and diseases of food crops. Plant Path. 60: 113-121. doi: 10.1111/j.1365-3059.02414.x.

Marchetti MA, Melching JS and Bromfield KR (1976). The effects of temperature and dew period on germination and infection by urediniospores of Phakopsora pachyrhizi. Phytopathology. 66: 461-463.

Marchetti MA, Uecker FA and Bromfield KR (1975). Uredinial development of Phakopsora pachyrhizi in soybeans. Phytopathology. 65: 822-823. doi: 10.1094/Phyto-65-822.

Martins JAS and Juliatti FC (2014). Genetic control of partial resistance to Asian soybean rust. Acta Sci Agron. 36(1): 11-17. doi:10.4025/actasciagron.v36i1.16919.

Martins JAS, Juliatti FC, Santos VA, Polizel AC, et al. (2007). Período latente e uso da análise de componentes principais para caracterizar a resistência parcial à ferrugem-da-soja. Summa Phytopathol. 33: 364-371. doi: $10.1590 / \mathrm{S} 0100-54052007000400008$

Mendiburu FD (2015). Agricolae: Statistical Procedures for Agricultural Research. R Package Version 1.2-3.

Melching JS, Dowler WM, Koogle DL and Royer M (1989). Effect of duration, frequency, and temperature of leaf wetness period on soybean rust. Plant Dis. 73: 117-122.doi: 10.1094/PD-73-0117.

Niks Re (1983). Comparative histology of partial resistance and the nonhost reaction to leaf rust pathogens in barley and wheat seedlings. Phytopathology. 73: 60-64. doi: 10.1094/Phyto-73-60.

Nunkumar A, Caldwell P and Pretorius Za (2013). Development of Phakopsora pachyrhizi on soybean at controlled temperature, relative humidity and moisture periods. South African J. Plant Soil. 26: 225-230. doi: 10.1080/02571862.2009.10639959.

Parlevliet JE and Kuiper HJ (1977). Partial resistance of barley to leaf rust, Puccinia hordei. IV. Effect of cultivar and development stage on infection frequency. Euphytica. 26(2): 249-255.doi: 10.1007/BF00026985.

Parlevliet JE (1978). Further evidence of polygenic inheritance of partial resistance in barley to leaf rust, Puccinia hordei. Euphytica. 27: 369-379.doi: 10.1007/BF00043161.

Parlevliet JE (1979). Components of resistance that reduce the rate of epidemic development. Annu. Rev. Phytop. 17: 203-222. doi: 10.1146/annurev.py.17.090179.001223.

Parlevliet JE (1983). Models explaining the specificity and durability of host resistance derived from the observations on the barley-Puccinia hordei system. In: Lamberti F, Waller JM, Van der Graaff NA (eds) Durable resistance in crops. Plenum Press, New York London, p. 57-80.

Parlevliet JE (1997). Present concepts in breeding for disease resistance. In: Brazilian Phytop. Congress. Fitop. Bras.22: 7-15.

Paul C, Hartman GL, Marois JJ, Wright DL, et al (2013). First report of Phakopsora pachyrhizi overcoming soybean genotypes with Rpp1 or Rpp6 rust resistance genes in field plots in the United States. Plant Dis. 97: 1379. doi:10.1094/PDIS-02-13-0182-PDN. 
Pierozzi PHB, Ribeiro AS, Moreira JUV, Laperuta LDC, et al (2008). New soybean (Glycine max Fabales, Fabaceae) sources of qualitative genetic resistance to Asian soybean rust caused by Phakopsora pachyrhizi (Uredinales, Phakopsoraceae). Genet. Mol. Biol. 31: 505-511. doi: 10.1590/S1415-47572008000300018.

Pivonia S and Yang XB (2004). Assessment of potential year-round establishment of soybean rust throughout the world. Plant Dis. 88: 523-529. doi: 10.1094/PDIS.2004.88.5.523.

Pivonia S and Yang XB (2006). Relating epidemic progress from a general disease model to seasonal appearance time of rusts in the United States: Implications for soybean rust. Phytopathology. 96: 400-407. doi: 10.1094/PHYTO-960400 .

R DEVELOPMENT CORE TEAM R (2017). A language and environment for statistical computing. R Foundation for Statistical Computing, Vienna, Austria. ISBN 3-900051-07-0, URL http://www.R-project.org.

Reis EM, Sartori AF and Câmara RK (2004). Modelo climático para a previsão da ferrugem da soja. Summa Phytopathol. 30: 290-292.

Santos JA, Juliatti FC, Santos VA, Polizel AC, et al. (2007). Caracteres epidemiológicos e uso da análise de agrupamento para resistência parcial à ferrugem da soja. Pesq. Agrop. Brasil. 42: 443-447. doi: 10.1590/S0100204X2007000300019.

Shaner G and Finney RE (1977). The effect of nitrogen fertilization on the expression of slow-mildewing resistance in knox wheat. Phytopathology. 70: 1183-1186. doi: 10.1094/Phyto-67-1051.

Silva VAS, Juliatti FC and Silva LAS (2007). Interação entre resistênciagenética parcial e fungicidas no controle da ferrugem asiática da soja. Pesq. Agrop. Brasil. 42: 1261-1268. doi: 10.1590/S0100-204X2007000900007.

Sinclair JB and Backman PA (1989). Compendium of soybean diseases. 3rd edition. St. Paul: American Phytopathology Society. p. 24-27

Souza AR and Fernandes JJ (2008).Efeito do período de molhamento foliar na ocorrência da ferrugem asiática (Phakopsora pachyrhizi) na soja (Glycine max). In: SEMANA ACADÊMICA, 5. Anais Uberlândia. Universidade Federal de Uberlândia.

Tschanz AT and Wang TC (1985). Interrelationship between soybean development, resistance, and Phakopsora pachyrhizi. Anais, Fifth International Congress of the Society for the Advanced of Breeding Research in Asia and Oceania, Bangkok, Thailand. P. 14-20.

Twizeyimana M and Hartman GL (2012). Pathogenic variation of Phakopsora pachyrhiziisolates on soybean in the United States from 2006 to 2009. Plant Dis. 96(1): 75-81. doi: 10.1094/PDIS-05-11-037.

Uchôa CN, Pozza EA, Albuquerque KS and Moraes WS (2012). Relação entre a temperatura e o molhamento foliar no monociclo da Sigatoka-negra. Summa Phytopathol. 38(2): 144-147. doi: 10.1590/S0100-54052012000200006.

Vale FXR, Zambolim L and Chaves GM (1990). Efeito do binômio temperatura duração do molhamento foliar sobre a infecção por Phakopsora pachyrhizi emsoja. Fitopatologia. 15(3): 200-202.

Vale FXR (1985). Aspectos epidemiológicos da ferrugem (Phakopsora pachyrhizi Sydow) da soja (Glycine max L. Merrill). 104p. Doctoral ThesisUniversidade Federal de Viçosa, Viçosa, MG.

Vallavielle-Pope C, Giosue S, Munk L, Newton Ac, et al. (2000). Assessmentof epidemiological parameters and their use in epidemiological and forescasting models of cereal airborne diseases. Agronomie. 20: 715-727.doi: 10.1051/agro:2000171

Walker DR, Harris DK, King ZR, Li Z, et al (2014). Evaluation of soybean germplasm accessions for resistance to Phakopsora pachyrhizi populations in the southeastern United States, 2009-2012. Crop Sci. 54: 1673-1689.

Wrather JA, Anderson Tr, Arsyad DM, Tan Y, et al (2001). Soybean disease loss estimates for the top ten soybean producing countries in 1998. Can. J. Plant Path. 23(2): 115-121. doi: 10.1080/07060660109506918.

Yang XB, Tschanz AT, Dowler W and Wang TC (1991). Development of yield loss models in relation to reductions of components of soybean infected withPhakopsora pachyrhizi. Phytopathology 81: 1420-1426. doi:10.1094/Phyto81-1420.

Yorinori JT (2005). A ferrugem "asiática" da soja no continente americano: evolução, importância econômica e estratégias de controle. In: Juliatti FC, Polizel AC, Hamawaki, OT(Org) In:Workshop brasileiro sobre a ferrugem asiática, 1.,Uberlândia.Coletânea. Uberlândia: EDUFU, p. 21-37.

Yorinori JT and WilfridoMP (2002). Ferrugem da soja: Phakopsora pachyrhizi Sydow. Londrina: Embrapa(Folder).

Zambenedetti EB, Alves EA, Pozza EA, Araújo EC, et al. (2007). Avaliação de parâmetros monocíclicos e da intensidade da ferrugem asiática (Phakopsora pachyrhizi) em diferentes genótipos de soja e posições de copa. Summa phytopathol.33(2): 178-181. doi:10.1590/S0100-54052007000200012. 